\title{
DETECTION OF QUORUM QUENCHING-PRODUCING BACTERIA FROM RHIZOSPHERE SOIL AS A BIOCONTROL AGENTS
}

\author{
Stella Magdalena $^{1 *}$, Inez Johanna ${ }^{2}$, Yogiara $^{3}$ \\ ${ }^{1}$ Department of Food Technology \\ Faculty of Biotechnology Atma Jaya Catholic University of Indonesia \\ Jl. Jend. Sudirman No.51, Kota Jakarta Selatan, DKI Jakarta. 12930 \\ ${ }^{2}$ Department of Biotechnology \\ Faculty of Biotechnology Atma Jaya Catholic University of Indonesia \\ Jl. Jend. Sudirman No.51, Kota Jakarta Selatan, DKI Jakarta. 12930 \\ ${ }^{3}$ Department of Magister Biotechnology \\ Faculty of Biotechnology Atma Jaya Catholic University of Indonesia \\ Jl. Jend. Sudirman No.51, Kota Jakarta Selatan, DKI Jakarta. 12930 \\ *E-mail: stella.magdalena@atmajaya.ac.id
}

\begin{abstract}
Quorum sensing is known as a communication mechanism among bacteria to control gene expression such as bioluminescence, pigmentation, and pathogenicity. Quorum quenching is known as inhibition of quorum sensing activity. In order to block quorum sensing activity, some bacteria produced enzymes which could degrade AHL, such as AHL-acylase, AHLlactonase, and AHL-oxidase and reductase. In this study, soil bacteria were isolated and screened for their quorum quenching activity. These isolates were divided into Streptomyces and non-Streptomyces isolates. Detection were done by using Chromobacterium violaceum as an indicator bacteria for pigment inhibition by quorum quenching activity. About 10 out of 695 isolates were shown to possess quorum quenching activity. These isolates were further identified by biochemical tests, Gram staining, and identified by $16 \mathrm{~S}$ rRNA sequencing. Four positive isolates showed similarity with Streptomyces sp., and 6 positive isolates were non-Streptomyces which showed similarity with Pseudomonas putida, Bacillus pumilus, Bacillus sp., Enterobacter ludwigii, and Enterobacter sp.
\end{abstract}

Keywords: quorum quenching, quorum sensing, rhizosphere, soil, Streptomyces

\section{INTRODUCTION}

$\mathrm{P}$ athogenic bacteria would cause infection to human host when sufficient bacteria are present to express their virulence gene. This mechanism related to quorum sensing mechanisms. In order to fight bacterial infection, researchers has found a powerful medicine, like antibiotic. Antibiotic would inhibit or kill pathogenic bacteria. However, wide use of antibiotic has inescapably resulted in the emergence of antibiotic resistance of pathogenic bacteria. Therefore, it has to be another way to fight bacterial infection. Another way to fight pathogenic bacteria is to inhibit their quorum sensing. This mechanism is known as quorum quenching. $\mathrm{N}$-acyl-homoserine lactone (AHL) is an autoinducer, as signal molecule, that produced by Gram-negative bacteria. Quorum quenching compounds could inhibit quorum sensing of pathogenic bacteria so that they could not sense their cell mass and would not cause virulence to the host (Mahmoudi et 
al., 2011; Kang et al., 2016; Haque et al., 2018). Quorum sensing inhibition can be done by degrading extracellular signal molecules using enzymatic activities (Abudoleh \& Mahasneh, 2017).

A culturable bacteria isolated from rhiosphere soil produced AHL degradation competency (Chan et al., 2011; Achari \& Ramesh, 2018). Streptomyces sp. were targeted as source of diverse quorum quenching agents, because these bacteria possess the capability to synthesise a variety of secondary metabolites, like hydrolytic enzymes (Tan et al., 2016; Velasco-Bucheli et al., 2020). The objective of this study was to isolate and detect rhizosphere soil bacteria from several places in Indonesia for its quorum quenching activity. This study could be used for further study of its possibility to be applied in pharmaceutical industry, especially to fight bacterial infection.

\section{MATERIALS AND METHODS}

\section{Isolation of Rhizosphere Soil Bacteria}

Rhizosphere soil samples from several places in Indonesia were collected from 15 $\mathrm{cm}$ depth after removing $3 \mathrm{~cm}$ soil surface. Soil samples were placed in plastic bags and kept at cool temperature for temporary storage. Each soil sample $1 \mathrm{~g}$ were placed in the oven with temperature adjusted to $70^{\circ} \mathrm{C}$ for an hour. Soil samples were suspended with 9 $\mathrm{ml}$ sterile distilled water and diluted until $10^{-2}$. A total of $100 \mu 1$ sample was spreaded onto Starch Casein Agar (SCA) at $25^{\circ} \mathrm{C}$ for 7 days and the media Luria Agar (LA) at $37^{\circ} \mathrm{C}$ for 1-2 days. Colonies with different morphology was isolated and purified. Streptomyces isolates were purified in Streptomyces Agar (SA), whereas nonStreptomyces isolates were purified in the LA media.

\section{Detection of Quorum Quenching Activity}

Quorum quenching activity was determined by well-diffusion method (Soundari et al., 2014) with modification. Chromobacter violaceum wild type were cultivated on Luria Broth (LB) subsequently incubated at $28^{\circ} \mathrm{C}$ for 24 hours. Streptomyces isolates were grown on Streptomyces Broth (SB) for 7 days at $25^{\circ} \mathrm{C}$ with agitation $120 \mathrm{rpm}$, whereas the non-Streptomyces isolates were grown in LB medium for 48 hours at $37^{\circ} \mathrm{C}$. After that, the suspension was centrifuged at $7000 \mathrm{x}$ g for 5 minutes. Several wells were made using sterile cork-borer. One hundred $\mu \mathrm{L}$ of $C$. violaceum $\left(\mathrm{OD}_{600}=0.4\right)$ was streaked on LA using sterile cotton bud. A total of $20 \mu \mathrm{l}$ supernatant from each isolates was inserted into each wells and the plates were incubated at $28^{\circ} \mathrm{C}$ for 24 hours. SB and LB were used as negative control. Quorum quenching activity was detected by inhibition of violacein production (no purple-pigmented colonies) around the wells.

\section{Biochemical Test and Gram Staining}

Biochemical test for Streptomyces isolates are motility, indole test, and catalase. Biochemical test for non-Streptomyces isolates are motility, indole test, catalase and oxidase test, urease production, citrate utilisation, hydrogen sulfide test (TSIA), and lysine decarboxilase. Gram staining were done to differentiate bacteria into Gram classification, and also to determine their morphology.

\section{Molecular Identification of Rhizosphere Soil Bacteria}

Total DNA genome extraction of positive isolates for quorum quenching activity were done using Promega DNA Purification Kit and used as DNA template for PCR 
amplification of 16S rRNA gene. The identification of the isolates was conducted using universal primer, namely 63F (5'-CAGGCCTAACACATGCAAGTC-3') and 1387R (5'GGGCGGWGTGTACAA GGC-3') (Marchesi et al., 1998). The $50 \mu \mathrm{L}$ reaction mixture contained of $0.5 \mu \mathrm{L}$ DNA template (100 ng), $2 \mu \mathrm{L}$ of forward primer $63 \mathrm{~F}, 2 \mu \mathrm{L}$ reverse primer $1387 \mathrm{R}, 25 \mu \mathrm{L}$ of Go Taq ${ }^{\circledR}$ Green (Promega) $2 \mathrm{x}$, and $20.5 \mu \mathrm{L}$ of $\mathrm{ddH}_{2} \mathrm{O}$.

PCR condition started with pre-denaturation at $94^{\circ} \mathrm{C}$ for 5 minutes. All cyclers were designed to perform 30 cycles consisting of denaturation at $94^{\circ} \mathrm{C}$ for 1 minutes, annealing at $56^{\circ} \mathrm{C}$ for 1 minute, and extension at $72^{\circ} \mathrm{C}$ for 1.5 minutes followed by a final extension step of post-extension at $72^{\circ} \mathrm{C}$ for 5 minutes. PCR products were visualized by agarose gel electrophoresis in 1\% agarose gel at 90 Volt for 60 minutes using 1x TAE buffer, visualized under UV light with the help of FloroSafe DNA Stain ( $1{ }^{\text {st }}$ BASE), and recorded with Gel Doc instrument (BioRad, USA).

PCR results of $16 \mathrm{~S}$ rRNA gene was purified and sequenced to determine the nucleotide order of DNA fragments of each isolate. Purification and sequencing were performed by Macrogen, Korea using ABI3730XL. Data analysis were done using BLAST program from National Centre for Biotechnology Information (NCBI) to identify positive isolates.

\section{RESULTS AND DISCUSSIONS}

\section{Isolation and Detection of Quorum Quenching Activity}

A total of 60 rhizosphere soil samples from several regions in Indonesia were screened for Streptomyces and non-Streptomyces isolates. In this study, 362 Streptomyces isolates and 333 non Streptomyces isolates were successfully isolated. These isolates were screened for its quorum quenching activity towards $C$. violaceum wild type as indicator bacteria.

Results showed that only $1.44 \%$ of total rhizosphere soil bacterial isolates were positive for quorum quenching activity towards the indicator bacteria (Figure 1). These isolates were isolate D, (1), SH21, PKS03, H, LSY13, FLB12, PB01, MKJ12, and PK01. Isolate D, (1), SH21, and PKS03 were characterized as Streptomyces from their morphology and growth in the cultivation medium, as the other isolates were characterized as non-Streptomyces. This results is consistence with previous research about the presence of quorum quenching activity from soil bacteria (Chan et al., 2011; Mahmoudi, Tabatabaei, \& Venturi, 2011; Chong et al., 2012; Chankhamhaengdecha et al., 2013; Hassan et al., 2016) This result was similar to previous study that most positive isolates were originated from turf soil or agricultural soil in plateau area (Wang \& Leadbetter, 2005).

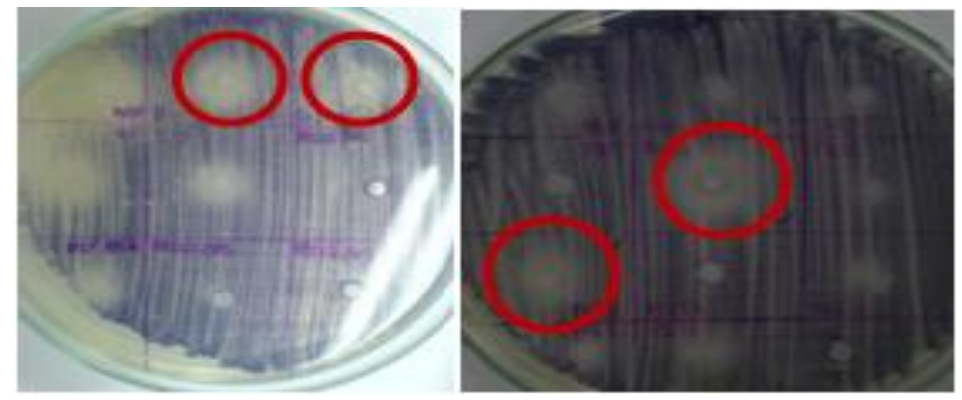

Figure 1. Quorum quenching activity of Streptomyces isolates (shown with red circle) 


\section{Biochemical Test and Gram Staining}

Positives isolates for quorum quenching were further identified by biochemical test and Gram staining. Characteristics of Streptomyces isolates were positive for hydrolysis casein, indole negative, and catalase positive (Table 1). Non-Streptomyces isolates showed different biochemical characteristics and morphology. Most of non-Streptomyces isolates were rod-shaped Gram negative bacteria (Table 2).

Table 1. Biochemical test of Streptomyces isolates from rhizosphere soil

\begin{tabular}{cccc}
\hline Isolates code & Casein hydrolysis & Indole & Catalase \\
\hline $\mathrm{D}$ & $(+)$ & $(-)$ & $(+)$ \\
\hline$(1)$ & $(+)$ & $(-)$ & $(+)$ \\
\hline $\mathrm{SH} 21$ & $(+)$ & $(-)$ & $(+)$ \\
\hline $\mathrm{PKS} 03$ & $(+)$ & $(-)$ & $(+)$ \\
\hline
\end{tabular}

Table 2. Biochemical test of non-Streptomyces isolates from Rhizosphere soil

\begin{tabular}{cccccccccc}
$\begin{array}{c}\text { Isolates } \\
\text { Code }\end{array}$ & Catalase & Oxidase & Citrate & Urease & TSIA & LD & Motility & Indole & $\begin{array}{c}\text { Gram } \\
\text { Staining }\end{array}$ \\
\hline H & ++ & - & + & - & $\begin{array}{c}\mathrm{A} / \mathrm{A} \\
\neq \text { gas }\end{array}$ & + & Motile & $-\begin{array}{c}\text { Gram }(-) \\
\text { Bacilli }\end{array}$ \\
\hline LSY13 & - & + & - & - & $\begin{array}{c}\mathrm{A} / \mathrm{K} \\
\neq \text { gas }\end{array}$ & + & Motile & $-\begin{array}{c}\text { Gram }(-) \\
\text { Bacilli }\end{array}$ \\
\hline FLB12 & - & - & + & + & $\begin{array}{c}\mathrm{K} / \mathrm{A} \\
\neq \text { gas }\end{array}$ & + & Motile & - & $\begin{array}{c}\text { Gram }(-) \\
\text { Bacilli }\end{array}$ \\
\hline PB01 & +++ & - & + & - & $\begin{array}{c}\text { K/A } \\
\neq \text { gas }\end{array}$ & - & $\begin{array}{c}\text { Non } \\
\text { motile }\end{array}$ & $-\begin{array}{c}\text { Gram }(+) \\
\text { Bacilli }\end{array}$ \\
\hline MKJ12 & - & + & + & - & $\begin{array}{c}\text { K/K } \\
\neq \text { gas }\end{array}$ & - & Motile & - & $\begin{array}{c}\text { Gram }(-) \\
\text { Bacilli }\end{array}$ \\
\hline PK01 & + & + & + & + & $\begin{array}{c}\text { A/A } \\
\neq \text { gas }\end{array}$ & - & $\begin{array}{c}\text { Non } \\
\text { motile }\end{array}$ & - & $\begin{array}{c}\text { Gram }(+) \\
\text { Bacilli }\end{array}$ \\
\hline A A
\end{tabular}

A: Acid, K: Alkaline, LD: Lysine Decarboxilase

\section{Molecular Identification of Rhizosphere Soil Bacteria}

PCR amplification of the 16S rDNA gene generated the amplicon size about 1300 bp (Figure 2). Isolate D, (1), SH21, and PKS03 similar to the genus Streptomyces sp (Table 3). In previous study, Streptomyces sp. produced extracellular AHL-acylase encoded by $a h l \mathrm{M}$ gene and could inhibit the violacein production of indicator bacteria (Sakr et al., 2015; Velasco-Bucheli et al., 2020).

GenBank database suggested isolate FLB12 and $\mathrm{H}$ belong to the genus Enterobacter sp. Isolate FLB12 share 97\% sequence identity with $16 \mathrm{~S}$ rRNA gene of Enterobacter ludwigii strain BIHB 336, whereas isolate $\mathrm{H}$ share $99 \%$ sequence identity with 16S rRNA gene of uncultured Enterobacter sp. clone F4aug.22. According to the database, isolate PB01 share $96 \%$ similarity to Bacillus pumilus strain JMC11, whereas isolate PK01 share 75\% similarity to Bacillus sp. G2-10 (Table 3). Bacillus sp. was known for their quorum quenching activity by producing AHL-lactonase which could inhibit violacein production of $C$. violaceum (Yin et al., 2012). This enzyme successfully interrupt the quorum sensing system of Aeromonas hydrophila (Chu et al., 2014; Chen et al., 2019; Zhou, Yu, \& Chu, 2019), Pseudomonas aeruginosa (Raafat, Ali-Tammam, \& Ali, 2019), and Vibrio parahaemolyticus DAHP1 (Vinoj et al., 2014). 


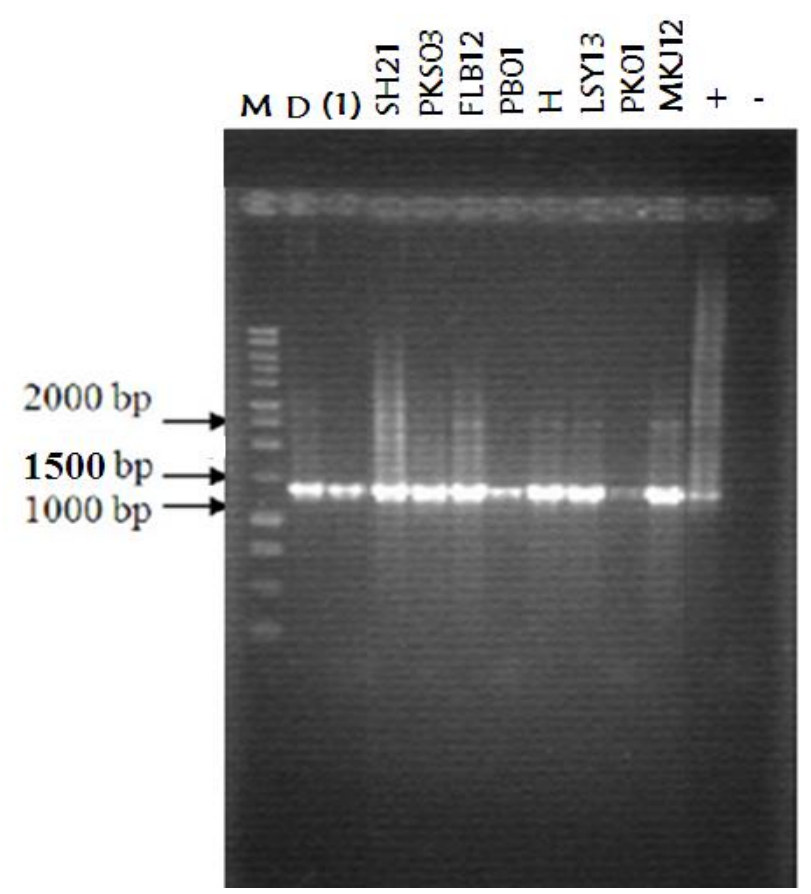

Figure 2. PCR amplification of positive isolates 16S rRNA genes Lane M: $1 \mathrm{~kb}$ DNA ladder. Positive control: bacterial isolates positive for $16 \mathrm{~S}$ rDNA gene; negative control: PCR mixtures without DNA template. The targeted amplicon size is $1300 \mathrm{bp}$.

Isolate LSY13 and MKJ12 share 99\% sequence identity with 16S rRNA gene of Pseudomonas putida strain TP0701 (Table 3). Pseudomonas sp. 1A1 was able to produce AHL-acylase and disrupted a broad range of AHLs (Cheong et al., 2013).

Table 3. Identification of positive isolates for quorum quenching activity

\begin{tabular}{|c|c|c|c|c|c|}
\hline Isolate & $\begin{array}{l}\text { Rhizosphere } \\
\text { soil sample }\end{array}$ & Location & $\begin{array}{c}\text { Soil } \\
\text { description }\end{array}$ & Similarity & $\begin{array}{l}\text { Max } \\
\text { Ident }\end{array}$ \\
\hline $\mathrm{D}$ & $\begin{array}{l}\text { Mango apple } \\
\text { tree }\end{array}$ & Cileungsi & Turf soil & Streptomyces sp. 2438 & $87 \%$ \\
\hline$(1)$ & Bananas tree & Cileungsi & Turf soil & Streptomyces sp. 2438 & $95 \%$ \\
\hline SH21 & Zallaca palm & Situgunung & Forest soil & Streptomyces sp. 2438 & $84 \%$ \\
\hline PKS03 & Livistonia sp. & Situgunung & Turf soil & Streptomyces sp. BC37 & $88 \%$ \\
\hline FLB12 & Poinciana tree & Borobudur & Turf soil & $\begin{array}{llr}\text { Enterobacter ludwigii } & \text { strain } \\
\text { BIHB } 336 & & \\
\end{array}$ & $97 \%$ \\
\hline PB01 & Palm tree & Bogor & Turf soil & Bacillus pumilus strain JCM11 & $96 \%$ \\
\hline $\mathrm{H}$ & Pine tree & Cileungsi & Turf soil & $\begin{array}{l}\begin{array}{l}\text { Uncultured Enterobacter } \\
\text { clone F4aug. } 22\end{array} \\
\end{array}$ & $99 \%$ \\
\hline LSY13 & $\begin{array}{c}\text { Leucaena } \\
\text { leucocephala }\end{array}$ & Sleman & $\begin{array}{l}\text { Agricultural } \\
\text { soil } \\
\end{array}$ & $\begin{array}{l}\text { Pseudomonas putida strain } \\
\text { ТР0701 }\end{array}$ & $99 \%$ \\
\hline PK01 & Papaya tree & Kaliurang & $\begin{array}{l}\text { Agricultural } \\
\text { soil }\end{array}$ & Bacillus sp. G2-10 & $75 \%$ \\
\hline MKJ12 & Mango tree & Jakarta & Turf soil & $\begin{array}{l}\text { Pseudomonas putida strain } \\
\text { TP0701 }\end{array}$ & $99 \%$ \\
\hline
\end{tabular}

Quorum quenching activity of rhizosphere soil bacteria could be used for further study for its application. Quorum quenching mechanism are proposed as an alternative to attenuate and fight bacterial infection, and also direct application of AHL-degrading bacteria as biocontrol agents against phytopathogenic bacteria (Garge \& Nerurkar, 2017; 
Ha et al., 2018; Alinejad et al., 2020; Vesuna \& Nerurkar, 2020).

\section{CONCLUSIONS}

In this study, ten soil bacterial isolates were known to possess quorum quenching activity towards indicator bacteria $C$. violaceum. Most of these bacteria were originated from rhizosphere soil samples which were taken from plateau. The ability of soil bacteria to perform quorum quenching mechanism as shown in this study could be used for further study of its possibility to be applied in pharmaceutical and agricultural industries.

\section{REFERENCES}

Abudoleh, S. M., \& Mahasneh, A. M. (2017). Anti-quorum sensing activity of substances isolated from wild berry associated bacteria. Avicenna Journal of Medical Biotechnology, 9(1), 23-30.

Achari, G.A., \& Ramesh, R. 2018. Characterization of quorum quenching enzymes from endophytic and rhizosphere colonizing bacteria. Biocatalysis and Agricultural Biotechnology, 13, 20-24. Doi. 10.1016/j.bcab.2017.11.004.

Alinejad, F., Shahryari, F., Eini, O., Sarafaz-Niko, F., Shekari, A., \& Setareh, M. (2020). Screening of quorum-quenching bacteria associated with rhizosphere as biocontrol agents of Pectobacterium carotovorum subsp. carotovorum. Archives of Phytopathology and Plant Protection, 53, (11-12), 509-523. Doi. 10.1080/03235408.20202.1761765.

Chan, K. G., Atkinson, S, Mathee, K., Sam, C. K., Chabra, S. R., Cámara, M., Koh, C. L., \& Williams, P. (2011). Characterization of N-acylhomoserine lactone-degrading bacteria associated with the Zingiber officinale (ginger) rhizosphere: co-existence of quorum quenching and quorum sensing in Acinetobacter and Burkholderia. BMC Microbiology, 11, 1-13. Doi. 10.1186/1471-2180-11-51.

Chankhamhaengdecha, S., Hongvijit, S., Srichaisupakit, A., Charnchai, P., \& Panbangred, W. (2013). Endophytic actinomycetes: a novel source of potential acyl homoserine lactone degrading enzymes. BioMed Research International, 2013, 1-9. Doi. 10.1155/2013/782847.

Chen, B., Peng, M., Tong, W., Zhang, Q., \& Song, Z. (2020). The quorum quenching bacterium Bacillus licheniformis T-1 protects zebrafish against Aeromonas hydrophila infection. Probiotics \& Antimicrobial Protein, 12, 160-171. Doi: 10.1007/s12602-018-9495-7.

Cheong, W. S., Lee, C. H., Moo, Y. H., Oh, H. S., Kim, S. R., Lee, S. H., Lee, C. H., \& Lee, J. K. (2013). Isolation and identification of indigenous quorum quenching bacteria, Pseudomonas sp. 1A1, for biofouling control in MBR. Industry \& Engineering Chemistry Research, 51, 10554-10560. Doi. 10.1021/ie303146f.

Chong, T. M., Koh, C. L., Sam, C. K., Choo, Y. M., Yin, W. F., \& Chan K. G. (2012). Characterization of quorum sensing and quorum quenching soil bacteria isolated from Malaysian tropical montane forest. Sensors, 12(4), 4846-4859. Doi: 10.3390/s120404846.

Chu, W., Zhou, S., Zhu, W., \& Zhuang, X. (2014). Quorum quenching bacteria Bacillus sp. QSI-1 protect zebrafish (Danio rerio) from Aeromonas hydrophila infection. Scientific Reports, 4, 1-6. Doi: 10.1038/srep05446.

Garge, S. S., \& Nerurkar, A. S. (2016). Evaluation of quorum quenching Bacillus spp. for their biocontrol traits against Pectobacterium carotovorum subsp. carotovorum. Biocatalysis and Agricultural Technology, 9, 48-57. Doi: 10.1016/j.bcab.2016.11.004.

Ha, N.T., Minh, T.Q., Hoi, P.X., Thuy, N.T.T., Furuya, N., \& Long H.H. (2018) Biological control of potato tuber soft rot using N-acyl-L-homoserine lactone-degrading endophytic bacteria. Current Science, 115(10), 1921-1927. Doi. 10.18520/cs/v115/110/1921-1927.

Haque, S., Ahmad, F., Dar, S. A., Jawed, A, Mandal, R. K. Wahid, M., Lohani, M., Khan, S., Singh, V., \& Akhter, N. (2018). Developments in strategies for quorum sensing virulence factor inhibition to combat bacterial drug resistance. Microbial Pathogenesis, 121, 293-302. Doi. 10.1016/j.micpath.2018.05.046.

Hassan, R., Shaaban, M.I., Bar, F.M.A., El-Mahdy, A.M., \& Shokralla, S. (2016). Quorum sensing inhibiting activity of Streptomyces coelicoflavus isolated from soil. Frontiers in Microbiology, 7 , 659, 1-12. Doi. 10.3389/fmicb.2016.00659.

Kang, J.I., Han, J.W., Jeon, B.J., \& Kim, B.S. (2016). Efficacies of quorum sensing inhibitors, piericidin A and glucopiericidin A, produced by Streptomyces xanthocidius KPP01532 for the control of potato soft rot caused by Erwinia carotovora_subsp. Atroseptica. Microbiological Research, 184, 32-41. Doi. 10.1016/j.micres.2015.12.005. 
Mahmoudi, E., Tabatabaei, B. E. S., \& Venturi, V. (2011). Virulence attenuation of Pectobacterium carotovorum using $\mathrm{N}$-acyl-homoserine lactone degrading bacteria isolated from potato rhizosphere. The Plant Pathology Journal, 27(3), 242-248. Doi. 10.5423/PPJ.2011.27.3.242.

Marchesi, J. R., Sato, T., Weightman, A. J., Martin, T. A. Fry, J. C., Hiom, S. J., \& Wade, W. G. (1998). Design and evaluation of useful bacterium-specific PCR primers that amplify genes coding for bacterial 16S rRNA. Applied and Environmental Microbiology, 64(2), 795-799.

Raafat, M. W., Ali-Tammam, M., \& Ali, A. E. (2019). Quorum quenching activity of Bacillus cereus isolate $30 \mathrm{~b}$ confers antipathogenic effects in Pseudomonas aeruginosa. Infection and Drug Resistance, 12, 1583-1596. Doi. 10.2147/IDR.S182889.

Sakr, M.M., Aboshanab, K.M.A., Aboulwafa, M.M., \& Hassouna, N.A-H. (2015). Characterization of the quorum quenching activity of Streptomyces minutiscleroticus: a new approach for infection control. African Journal of Microbiology Research, 9(8), 492-502. Doi. 10.5897/AJMR2014.7316.

Soundari, A. P. G., Nagarajan, C., Mani, V. M., \& Priyadarisini, V. B. (2014). Quorum quenching activity of pigments produced by Actinomycetes. International Journal of Science and Research, 3(9), 22522257.

Tan, L. T. H., Chan, K. G., Lee, L. H., \& Goh, B. H. (2016). Streptomyces bacteria as potential probiotics in aquaculture. Frontier in Microbiology, 7, 79, 1-8. Doi. 10.3389/fmicb.2016.00079.

Velasco-Buchel, R., Hormigo, D., Fernández-Lucas, J., Torres-Ayuso, P., Alfaro-Ureña, Y., Saborido, A. I., Serrano-Aguirre, L., Garcǐa, J. L., Ramón, F., Acebal, C., Santos, A., Arroyo, M., \& de la Mata, I. (2020). Penicillin acylase from Streptomyces lavendulae and aculeacin A acylase from Actinoplanes utahensis: two versatile enzymes as useful tools for quorum quenching process. Catalysts, 10, 730, 1-19. Doi. 10.3390/catal10100730.

Vesuna, A. P., \& Nerurkar, A. S. (2020). Biocontrol impact of AHL degrading actinobacteria on quorum sensing regulated virulence of phytopathogen Pectobacterium carotovorum subsp. carotovorum BR1. Plant Soil, 453, 371-388. Doi. 10.1007/s1104-020-04623-z.

Vinoj, G., Vaseeharan, B., Thomas, S., Spiers, A.J., \& Shanthi, S. (2014). Quorum-quenching activity of the AHL-lactonase from Bacillus licheniformis DAHB1 inhibits Vibrio biofilm formation in vitro and reduces shrimp intestinal colonization and mortality. Marine Biotechnology, 16, 707-715. Doi. 10.1007/s10126-014-9585-9.

Wang, Y. J., \& Leadbetter, J. R. (2005). Rapid acyl-homoserine lactone quorum signal biodegradation in diverse soil. Applied and Environmental Microbiology, 71(3), 1291-1299. Doi. 10.1128/AEM.71.3.1291-1299.2005.

Yin, W. F., Tung, H. J., Sam, C. K., Koh, C. L., \& Chan, K. G. (2012). Quorum quenching Bacillus sonorensis isolated from soya sauce fermentation brine. Sensors, 12, 4065-4073. Doi. $10.3390 / \mathrm{s} 120404065$.

Zhou, S., Yu, Z., \& Chu, W. (2019). Effect of quorum quenching bacterium Bacillus sp. QSI-1 on protein profiles and extracellular enzymatic activities of Aeromonas hydrophila YJ-1. BMC Microbiology, 19, 135, 1-9. Doi. 10.1186/s12866-019-1515-6 